\title{
PANDEMI COVID-19 DALAM KACAMATA ISLAM
}

\author{
Titin Nurhidayati ${ }^{1}$, \\ M. Nafiur Rofiq ${ }^{2}$ \\ Institut Agama Islam Al-Falah As-Sunniyyah Kencong Jember \\ titinnurhidayati77@gmail.com; mnafurrofiq@gmail.com
}

\begin{abstract}
At the end of 2019 almost all countries were affected by thevirus outbreak Covid-19which caused a fairly high death rate. Coronaviruses (CoV) cause flu to more serious illnesses such as (MERS$\mathrm{CoV}$ ) and (SARS-CoV). The outbreak of this virus has caused paralysis of vital sectors such as economic, social, political, cultural and even religious. This pandemic condition makes everyone adapt to new habits. Therefore, the termappears new normal or a new life orderwhich is often heard due to this pandemic. This pandemic requires the state to issue rules and policies. With the outbreak of the covid19 virus, we as believers do not need to worry about dealing with it, but we must remain vigilant. Always ask for protection from God, pray, strive to do what is recommended to prevent the transmission of the covid-19 virus outbreak, by always maintaining cleanliness and always washing hands, Large-Scale Social Restrictions, rest assured that the healing that will be given God, always be patient and grateful, and trust in God and always believe in the healing that will be given by God Keywords: Pandemic, Coronavirus Disease, and Islamic Perspective
\end{abstract}

\begin{abstract}
Abstrak
Pada akhir tahun 2019 terjadi hampir di seluruh negara terkena wabah virus covid-19 yang menyebabkan angka kematian yang cukup tinggi. Coronaviruses $(\mathrm{CoV})$ menyebabkan timbulnya penyakit flu sampai yang lebih serius seperti (MERS-CoV) dan (SARS-CoV). Mewabahnya virus ini menyebabkan kelumpuhan sektor vital seperti ekonomi, sosial, politik, budaya dan bahkan agama. Kondisi pandemi ini membuat setiap orang untuk beradaptasi kebiasaan baru. Karenanya muncul istilah new normal atau tatanan kehidupan baru yang sering sekali terdengar akibat pandemi ini. pandemi ini mengharuskan negara menerbitkan aturan dan kebijakan. Dengan adanya wabah virus covid-19 ini kita sebagai seorang mukmin tidak perlu khawatir dalam menghadapinya, tetapi kita harus tetap waspada. Selalu meminta perlindungan kepada Allah Swt, berdoa, berikhtiar dengan melakukan hal yang dianjurkan untuk pencegahan penularan wabah virus covid-19 tersebut, dengan selalu menjaga kebersihan dan selalu mencuci tangan, Pembatasan Sosial Berskala Besar, yakinlah kesembuhan yang akan diberikan Allah SWT, selalu bersabar dan bersyukur, serta tawakal kepada Allah Swt dan selalu yakin akan kesembuhan yang akan diberikan oleh Allah SWT.
\end{abstract}

Kata Kunci: Pandemi, Coronavirus Disease, dan Perspektif Islam

\footnotetext{
${ }^{1}$ Dosen Tetap IAI Al-Falah As-Sunniyyah Kencong Jember

${ }^{2}$ Dosen Tetap IAI Al-Falah As-Sunniyyah Kencong Jember
} 


\section{PENDAHULUAN}

Dunia Internasional saat ini telah mengalami dampak dari wabah atau penyebaran dari Coronavirus. Virus ini pertama kali muncul di akhir Desember 2019 di Wuhan, China. Virus yang baru teridentifikasi ini memiliki tingkat penyebaran yang sangat cepat. Dalam kurun waktu kurang dari 4 bulan Coronavirus sudah menyebar di seluruh dunia. Pada 19 Maret 2020 WHO menyatakan wabah Coronavirus ini sebagai pandemi yang terjadi secara luas di seluruh dunia. Dan penyakit ini telah menjadi masalah bersama di seluruh negara-negara di dunia tak terkecuali Indonesia.

Penyebaran pandemi yang sangat cepat ini sangat menggemparkan negara-negara dunia dan menjadi pandemi dengan jumlah total korban terinfeksi terbanyak sepanjang sejarah manusia. Mewabahnya virus ini menyebabkan kelumpuhan sektor vital seperti ekonomi, sosial, politik, budaya dan bahkan agama. Kondisi ini telah menjadi sebuah bencana yang amat menakutkan dan ditambah belum adanya temuan obat atas virus ini. Sehingga membuat setiap negara telah membuat sebuah kebijakan-kebijakan serta strategi untuk mencegah dan memutus mata rantai penyebaran virus ini.

Kondisi pandemi ini membuat setiap orang untuk beradaptasi kebiasaan baru. Karenanya muncul istilah new normal atau tatanan kehidupan baru yang sering sekali terdengar akibat pandemi ini. pandemi ini mengharuskan negara menerbitkan aturan dan kebijakan. Seperti, pembatasan sosial atau social distancing, selalu memakai masker, hingga aturan yang membatasi kegiatan beragama masyarakat. Lingkungan dan kebiasaan baru ini menyebabkan masyarakat mengalami guncangan dan kegalauan atau biasa disebut culture shock. ${ }^{3}$ Culture shock merupakan proses yang dilalui seseorang sewaktu dia mengalami situasi atau lingkungan yang baru dan tidak familier, sehingga memerlukan pengembangan mode baru dari representasi simbolis dan perspektif baru terhadap diri sendiri, orang lain, dan lingkungan.

Belakangan diketahui bahwa dua orang (perempuan berusia 31 tahun dan ibunya berusia 64 tahun) mengetahui status mereka yang terinfeksi dari berita, dan bahwa presiden mengumumkan hal tersebut kepada publik sebelum petugas kesehatan memberitahukan kepada mereka secara langsung. ${ }^{4}$ Jika pada 2 Maret 2020 ditemukan 2 pasien positif covid-19, maka pada 24 Maret 2020 jumlah kasus telah melonjak drastis menjadi 686 di mana hanya 30 orang yang dinyatakan sembuh dan 55 orang meninggal (bnpb.go.id, 24 Maret 2020). ${ }^{5}$ Walaupun kasus positif corona di Indonesia terbilang sedikit dibanding negara lain, namun rasio kematian atau death rate mencapai $8,3 \%$ yaitu dua kali lipat tingkat kematian rata-rata dunia

\footnotetext{
3 Tri Ameliyaningsih* Eri Kartika* and Dimas Teguh Prasetyo, "Patub Kepada Tuban Atau Pemerintab? Culture Shock Masyarakat Muslim Indonesia Di Tengah Pandemi Covid-19,” 2, 3 (November 2020).

4 A Ibrahim Almuttaqi, “Kekacauan Respons Terhadap COVID-19 Di Indonesia," The Insights, 1, no. 13 (2020), 1-7.

5 Debora Sanur, "Wacana Kebijakan Lockdown Dalam Menghadapi Covid-19 Di Indonesia,"12, no. 6 (2020): 25-30.
}

63| Falasifa, Vol. 12 Nomor 2 September 2021 
yang terhitung 4,07\%. ${ }^{6}$ Lima provinsi tertinggi dalam kasus covid-19 adalah Jakarta (675), Jawa Barat (149), Banten (106), Jawa Timur (90), dan Jawa Tengah (63) (Kementerian Kesehatan Republik Indonesia, 2020). ${ }^{7}$ Penyakit covid-19 yang timbul disebabkan oleh virus corona merupakan penyakit jenis baru yang sebelumnya belum pernah menjangkit manusia(World Health Organization, 2019). ${ }^{8}$

Corona virus disease (covid-19) adalah jenis virus baru yang menyerang imunitas tubuh serta dapat menyebabkan kematian. ${ }^{9}$ Gejala covid-19 umumnya berupa demam $38^{\circ} \mathrm{C}$, batuk kering, dan sesak nafas serta dampak paling buruk untuk manusia ialah kematian. ${ }^{10}$ WHO merekomendasikan cara pencegahan tertularnya covid-19 pada diri manusia adalah dengan cara melakukan tahap-tahap dasar, mulai dengan cara mencuci tangan secara rutin menggunakan alkohol atau sabun dan air, melakukan pyhsical distancing dengan orang yangtimbul gejala batuk atau bersin, menutup mulut ketika batuk atau bersin, serta melakukan pengobatan ketika merasa timbul gejala covid-19. ${ }^{11}$ Proteksi dasar dilakukan karena sampai saat ini belum ditemukan obat untuk menyembuhkan wabah virus covid-19 dan agar tidak mudah tertular. Beberapa negara seperti Amerika berusaha mengembangkan vaksin berbasis RNA dan DNA, Perancis memodifikasi vaksin campak sehingga dapat digunakan untuk virus covid-19. ${ }^{12}$

Guncangan akibat kebiasaan yang terjadi pada masyarakat ini menjadi problematika khususnya masyarakat Indonesia yang memiliki tradisi dan kebiasaan yang banyak melibatkan banyak orang. Seperti aturan pembatasan ritual yang membatasi kebiasaan sholat berjamaah di masjid, dan pembatasan ritual agama lainnya seperti ritual mingguan umat kristen di gereja. hal ini menuai pro dan kontra pada masyarakat. Sebagian menerima dan mentaati aturan protokol kesehatan oleh pemerintah, sebagian lain menolak dan melanggarnya dengan berbagai alasan, diantara yang menolak ada yang menggunakan agama sebagai alasannya untuk menolak.

\footnotetext{
${ }^{6}$ Kasiano Vitalio Louis IX King, Anggita Dwi Ardani, "Melawan Corona: Solid Walau Berjarak,” 2020, 1-8.

${ }^{7}$ Ramadhan Tosepu et al., "Correlation Between Weather and Covid-19 Pandemic in Jakarta, Indonesia," Science of The Total Environment 725 (2020): 1-4, https://doi.org/10.1016/j.scitotenv.2020.138436.

${ }^{8}$ Nailul Mona, "Konsep Isolasi Dalam Jaringan Sosial Untuk Meminimalisi Efek Contagius (Kasus Penyebaran Virus Corona Di Indonesia)," Jurnal Sosial Humaniora Terapan, 2, no. 2 (2020): 117-25.

9 Tarisa Novita Indana Zulva, "Covid-19 Dan Kecenderungan Psikosomatis," Journal of Chemical Information and Modeling, 2020, 1-4, https://doi.org/10.1017/CBO9781107415324.004.

10 Surotul Ilmiyah Adib Rifqi Setiawan, "Lembar Kegiatan Siswa Untuk Pembelajaran Jarak Jauh Berdasarkan Literasi Saintifik Pada Topik Penyakit Coronavirus 2019 (COVID-19),” 4 (2020): 1-9, https://doi.org/.1037//0033-2909.I26.1.78

${ }^{11}$ Adityo Susilo et al., "Coronavirus Disease 2019: Tinjauan Literatur Terkini Coronavirus Disease 2019: Review of Current Literatures,” Jurnal Penyakit Dalam Indonesia, 7, no. 1 (2020): 45-67.

12 N. S. P. Suni, "Kesiapsiagaan Indonesia Menghadapi Potensi Penyebaran Corona," Pusat Penelitian Badan Keahlian DPR RI XII, no. 3 (2020): 13-18.
} 
Titin Nurbidayati

M. Nafiur Rofiq

\section{PEMBAHASAN}

\section{Coronavirus Disease (COVID-19)}

Kementerian Kesehatan Indonesia menjelaskan bahwa Coronavirus merupakan keluarga besar virus yang menyebabkan penyakit pada manusia dan hewan. Pada manusia biasanya menyebabkan penyakit infeksi saluran pernapasan, mulai flu biasa hingga penyakit yang serius seperti Middle East Respiratory Syndrome (MERS) dan Sindrom Pernafasan Akut Berat/ Severe Acute Respiratory Syndrome (SARS). COVID-19 adalah virus jenis baru yang ditemukan sejak kejadian luar biasa muncul di Wuhan Cina, pada Desember 2019, kemudian diberi nama Severe Acute Respiratory Syndrome Coronavirus 2 (SARSCOV2), dan menyebabkan penyakit Coronavirus Disease-2019 (COVID-19).

Seperti penyakit pernapasan lainnya, COVID-19 dapat menyebabkan gejala ringan termasuk pilek, sakit tenggorokan, batuk, dan demam. ${ }^{13}$ Sekitar $80 \%$ kasus dapat pulih tanpa perlu perawatan khusus. Sekitar 1 dari setiap 6 orang mungkin akan menderita sakit yang parah, seperti disertai pneumonia atau kesulitan bernafas, yang biasanya muncul secara bertahap. Walaupun angka kematian penyakit ini masih rendah, namun bagi orang yang berusia lanjut, dan orang-orang dengan kondisi medis yang sudah ada sebelumnya (seperti diabetes, tekanan darah tinggi dan penyakit jantung), mereka biasanya lebih rentan untuk menjadi sakit parah. Penyakit ini dapat menyebar melalui tetesan kecil (droplet) dari hidung atau mulut pada saat batuk atau bersin. Droplet tersebut kemudian jatuh pada benda di sekitarnya. Kemudian jika ada orang lain menyentuh benda yang sudah terkontaminasi dengan droplet tersebut, lalu orang itu menyentuh mata, hidung atau mulut (segitiga wajah), maka orang itu dapat terinfeksi COVID-19. Atau bisa juga seseorang terinfeksi COVID-19 ketika tanpa sengaja menghirup droplet dari penderita. Inilah sebabnya mengapa kita penting untuk menjaga jarak. ${ }^{14}$

COVID-19 termasuk dalam keluarga besar coronavirus yang sama dengan penyebab SARS pada tahun 2003, hanya berbeda jenis virusnya. Gejalanya mirip dengan SARS, namun angka kematian SARS (9,6\%) lebih tinggi dibanding COVID-19 (kurang dari 5\%), namun kasus COVID-19 jauh lebih banyak dibanding SARS. WHO melaporkan jumlah kasus positif SARS di seluruh dunia mencapai 8.437 orang. ${ }^{15}$ Maka jika dibandingkan dengan kasus positif pada saat ini, COVID-19 memiliki jumlah kasus

\footnotetext{
${ }^{13}$ Eman Supriatna, "Wabah Corona Virus Disease Covid 19 Dalam Pandangan Islam,” n.d., 12.

${ }^{14}$ Kemkes, dan Jertanyaan Jawaban Terkait https://www.kemkes.go.id/article/view/20031600011/pertanyaan-dan-jawaban-terkait-covid-19.html

15 CNN Indonesia, Membandingkan Wabah SARS, MERS, dan Virus Corona, Jumat, 13/03/2020 https://www.cnnindonesia.com/internasional/20200312160647-113-482934/membandingkan-wabah-sars-mers-dan-viruscorona

65| Falasifa, Vol. 12 Nomor 2 September 2021
} 
lebih dari 21 ribu kali lebih banyak dibanding SARS. ${ }^{16}$ Virus ini juga memiliki penyebaran yang lebih luas dan lebih cepat ke beberapa negara dibanding SARS. Penyebarannya yang sangat cepat membuat virus ini sebagai virus yang berbahaya, terlebih virus ini belum memiliki obat karna virus ini adalah tipe virus yang baru.

\section{Kebijakan pemerintah}

Risiko berbahaya dari Covid-19 yang penularannya sangat cepat mendesak pemerintah Indonesia mengambil strategi dan kebijakan demi memutus mata rantai penularan. Diantaranya: Peraturan Pemerintah Nomor 21 tahun 2020 tentang Pembatasan Sosial Berskala Besar dalam rangka Percepatan Penanganan Corona Virus Disease 2019 (Covid-19) ditetapkan pada 31 Maret 2020. Pemerintah Daerah (Pemda) dapat melakukan Pembatasan Sosial Berskala Besar (PSBB) untuk satu provinsi atau kabupaten/kota tertentu. PSBB dilakukan dengan pengusulan oleh gubernur/bupati/walikota kepada Menteri Kesehatan.

Peraturan Menteri Kesehatan No. 9 Tahun 2020 tentang Pedoman PSBB dalam rangka Percepatan Penanganan Covid-19 ditetapkan pada 3 April 2020. Kebijakan PSBB antara lain: 1) Peliburan sekolah dan tempat kerja; 2) Pembatasan kegiatan keagamaan; 3) Pembatasan kegiatan di tempat/fasilitas umum; 4) Pembatasan kegiatan sosial budaya; 5) Pembatasan moda transportasi; dan 6) Pembatasan kegiatan lainnya terkait aspek pertahanan dan keamanan.

Wabah covid-19 yang terjadi saat ini ada kesamaan dengan pada zaman Nabi yang juga sama terjadi wabah menular dan mematikan. Cara pencegahannya pun sama, walaupun wabah covid-19 sampai saat ini belum ditemukan obat penyembuhnya. Mari kita kembali mengingat kejadian wabah yang terjadi pada zaman Rasulullah. Pada zaman Rasulullah juga terjadi wabah yang menyerang kaum Rasulullah. Tetapi bukan virus covid-19 seperti pada zaman sekarang ini. Wabah tersebut adalah kusta atau lepra. Kusta adalah wabah yang menular dan mematikan sebelum ditemukan obatnya. Penyakit kusta merupakan penyakit menular menahun disebabkan oleh kuman mycobacterium leprae yang terutama menyerang saraf tepi, kulit dan organ tubuh lain kecuali susunan saraf pusat. ${ }^{17}$ Secara psikologis bercak, benjol-benjolan pada kulit membentuk paras yang menakutkan,

\footnotetext{
${ }^{16}$ Andari Wulan Nugrahani, Update Corona Global 25 Juni 2021 Siang: Jumlab Kasus Infeksi Covid di Selurub Dunia 180,7 Juta, https://www.tribunnews.com/corona/2021/06/25/update-corona-global-25-juni-2021-siang-jumlah-kasus-infeksicovid-di-seluruh-dunia-1807-juta.

17 Rilauni Angelina Mongi, "Gambaran Persepsi Penderita Tentang Penyakit Kusta Dan Dukungan Keluarga Pada Penderita Kusta di Kota Manado," 2012, bttp://fkm.unsrat.ac.id/wp- content/uploads/2012/10/RilauniMongi.pdf.
} 
kecacatannya juga memberi gambaran yang menakutkan, hal ini menyebabkan penderita kusta merasa rendah diri, depresi, dan menyendiri. ${ }^{18}$ Penyakit kusta ditularkan melalui kontak langsung melalui kulit dan saluran pernapasan secara berulang-ulang dan dalam jangka waktu yang lama (Depkes RI, 2005). ${ }^{19}$

Pada saat itu Nabi Muhammad SAW merupakan kepala negara dan pemimpin agama, semua urusan dunia atau kepentingan akhirat merupakan pedoman untuk kaumnya hingga sekarang, karena wahyu datangnya langsung dari Allah SWT dalam bentuk perintah atau larangan. ${ }^{20}$ Selain kusta, saat Nabi Muhammad SAW melakukan hijrah ke Madinah juga terdapat wabah. Nabi Muhammad SAW memerintahan kepada para pengikutnya agar bersabar dan selalu mengharapkan pertolongan yang datang dari Allah SWT. Disebutkan pada Hadits Riwayat Bukhari yaitu bagi orang yang betsabar dijanjikan surga dan pahala untuknya Karena kusta tersebut sangat mudah menular, maka Nabi pernah memperingkatkan kepada kaumnya untuk jangan mendekati wilayah yang sedang terjangkit wabah tersebut. Pada hadits riwayat Bukhari menjelaskan "Jika kamu mendengar wabah di suatu wilayah, maka janganlah kalian memasukinya. Tapi jika terjadi wabah di tempat kamu berada, maka jangan tinggalkan tempat itu." Hadits tersebut sangat mirip dengan kebijakan yang diambil oleh pemerintah daerah saat terjadinya wabah virus covid-19, yaitu karantina wilayah. Karantina wilayah merupakan kegiatan pembatasan penduduk pada suatu wilayah dan juga termasuk wilayah pintu masuk dan isinya yang ada dugaan tertular penyakit atau terpapar covid-19 untuk mencegah penyebaran virus penyakit atau yang terkontaminasi (Pasal 1 angka 10 UU Kekarantinaan Kesehatan). ${ }^{21}$ Pasal 9 Undang-Undang dengan nomor 6 tahun 2018 dijelaskan tujuan diselenggarakannya kegiatan karantina wilayah yaitu agar masyarakat terlindungi dari covid-19 dan meningkatkan keutuhan ketahanan Nasional pada bidang kesehatan didalam masyarakat serta memberi jaminan pelindungan maupun kepastian hukum untuk masyarakat serta petugas di bidang

\footnotetext{
${ }^{18}$ Tinuk Istiarti and Laksmono Widagdo, "Faktor-Faktor Yang Melatarbelakangi Persepsi Penderita Terhadap Stigma Penyakit Kusta," Promosi Kesehatan Indonesia, 4, no. 1 (2009): 18-24, https://doi.org/10.14710/jpki.4.1.1824.

19 Andy Muharry, "Faktor Risiko Kejadian Kusta," Kesehatan Masyarakat, 9, no. 2 (2014): 82-174, https://doi.org/10.22146/bkm.25569.

20 Mukharom Mukharom and Havis Aravik, "Kebijakan Nabi Muhammad SAW Menangani Wabah Penyakit Menular Dan Implementasinya Dalam Konteks Menanggulangi Coronavirus Covid-19," SALAM: Jurnal Sosial Dan Budaya Syar-I, 7, no. 3 (2020): 239-46, https://doi.org/10.15408/sjsbs.v7i3.15096

21 Dalinama Telaumbanua, "Urgensi Pembentukan Aturan Terkait Pencegahan Covid-19 Di Indonesia," QALAMUNA: Jurnal Pendidikan, Sosial, dan Agama, 12, no. 1 (2020): 59-70, https://doi.org/10.37680/qalamuna.v12i01.290.

67| Falasifa, Vol. 12 Nomor 2 September 2021
} 
Kesehatan, $^{22}$ gunanya adalah untuk mengetahui apakah pendatang tersebut muncul gejala-gejala tertular virus covid-19. Apabila muncul gejala-gejala tersebut, akan dibawa ke rumah sakit untuk penanganan lebih lanjut.

Nabi juga memerintahkan umatnya untuk tidak melihat atau mendekati orang yang terjangkit penyakit kusta tersebut. Seperti pada Hadits Riwayat Bukhari yang memiliki makna jangan melihat terus menerus kepada orang yang terkena kusta. Langkah physical distancing yang diambil pemerintah mirip dengan hadits tersebut. Physical distancing adalah menjaga jarak fisik, dari orang A ke B disarankan berjarak satu meter. Physical distancing dilakukan untuk mengurangi resiko penularan covid-19.

Sebagai negara dengan mayoritas penduduk muslim, kebijakan PSBB memunculkan kekhawatiran terhadap kebiasaan umat muslim di Indonesia. Salah satunya terkait aktivitas keagamaan di masjid. Untuk menjawab keresahan tersebut, Majelis Ulama Indonesia (MUI) mengeluarkan fatwa Nomor 14 Tahun 2020 (14/2020) tentang Penyelenggaraan Ibadah dalam Situasi Terjadi Wabah Covid19. Fatwa MUI 14/2020 berisi himbauan beribadah selama pandemi Covid-19. Fatwa tersebut mengandung pemahaman bahwa tiap muslim harus saling menjaga keselamatan bersama. Orang yang sedang sakit sebaiknya beribadah di rumah. Bahkan, di wilayah yang penyebaran Covid-19 cukup mengkhawatirkan, masyarakat muslim tidak diperbolehkan untuk beribadah bersama-sama di masjid maupun tempat umum lainnya. Meskipun fatwa sudah diterbitkan, umat muslim Indonesia sepertinya belum sepenuhnya sepakat.

Masa pandemi ini umat beragama harus siap dengan perubahan aspek kehidupan, termasuk pola ibadah berjamaah mereka dari ruang publik ke ruang privat, dari tempat ibadah ke rumah. Sehingga culture shock yang dialami tidak membawa mereka kepada hal-hal yang merugikan, seperti risiko tertularnya Covid-19 saat melaksanakan ritual keagamaan secara bersama-sama. Selain itu masyarakat muslim sebagai penduduk mayoritas di Indonesia, memiiliki pemimpin yaitu para ulama yang tergabung dalam Majelis Ulama Indonesia (MUI). Dengan demikian, segala kepentingan masyarakat muslim diatur dan dilindungi oleh MUI. Oleh karena itu, masyarakat muslim tidak perlu resah terkait pelaksanaan ibadah di tengah pandemi Covid-19 dan dianjurkan tetap mematuhi fatwa yang dikeluarkan oleh MUI. ${ }^{23}$ Demi kesehatan dan keselamatan di masa pandemi yang mewabah di seluruh dunia ini, yang mana

22 Annissa Rezki Nur Rohim Yunus, "Kebijakan Pemberlakuan Lock Down Sebagai Antisipasi Penyebaran Corona Virus Covid-19," Jurnal Sosial Dan Budaya Syar-I, 7, no. 3 (2020): 38-227, https://doi.org/10.15408/sjsbs.v7i3.15083.

23 Tri Ameliyaningsih* Eri Kartika* and Dimas Teguh Prasetyo, "Patub Kepada Tuhan Atau Pemerintah? Culture Shock Masyarakat Muslim Indonesia Di Tengah Pandemi Covid-19.'

Falasifa, Vol. 12 Nomor 2 September 2021 | 68 
wabah ini sebagai cobaan dan ujian bagi umat manusia dan berdampak pada orang-orang yang baik. ${ }^{24}$ Dan tentu itu semua adalah ketentuan dari Allah SWT.

\section{Patuh pada tuhan atau pemerintah?}

Berbagai kebijakan pemerintah telah di tebitkan mulai dari himbauan untuk selalu menjaga kebersihan dengan mencuci tangan secara teratur setelah beraktivitas, menjaga jarak (social distancing), isolasi mandiri, menghindari kontak fisik jabat tangan dan lain sebagai atau yang disebut (physical distancing), hingga pemberlakukan kebijakan resmi lainnya seperti Pembatasan Sosial Berskala Besar (PSBB). Beberapa kebijakan ini tentu untuk memutus matarantai penyebaran Covid-19. Kebijakan tersebut ditaati sebagian masyarakat dan diabaikan oleh sebagian yang lain, diantara alasan penolakannya adalah karena mereka menganggap kebijakan tersebut tidak sesuai dengan ajaran Islam. Maka bagaimana sebenarnya kacamata Islam dalam menghadapi wabah yang terjadi seperti saat ini?

a. Menjaga kebersihan dan selalu mencuci tangan

Tentu aturan ini sangat sejalan dengan ajaran agama Islam, karena agama Islam mengajarkan kebersihan Salah satu sebab penyakit mudah menyebar adalah karena aspek kebersihan diri maupun lingkungan yang tidak terjaga dengan baik. Aspek kebersihan merupakan salah satu hal penting yang ditekankan dalam Islam. Bahkan kebanyakan kajian kitab-kitab Fiqh diawali dengan bab kebersihan.

b. Pembatasan Sosial Berskala Besar

Dalam kitab Tibb an-Nabawy karya Ibnu qoyyim ${ }^{25}$ dijelaskan bahwa wabah juga terjadi pada masa Rasulullah SAW. Dalam hadist yang diriwayatkan Imam Al-Bukhori dan Muslim, Rasulullah SAW bersabda:

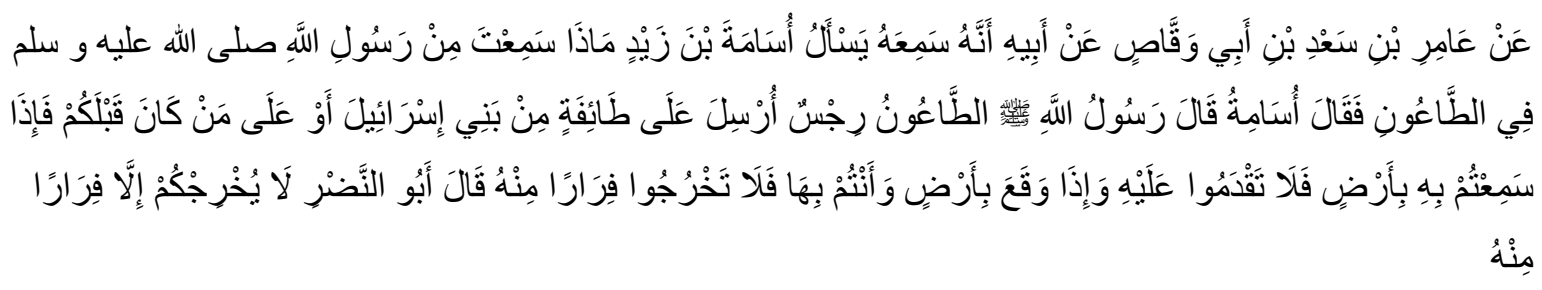

“Wabah Tho'un ialah kotoran yang dikirim kepada bani Israil atau kepada kaum sebelummu, maka jika kamu mendengarnya dalam suatu negeri, maka jangan kamu mendatanginya, dan jika terjadi dalam suatu negeri dan kamu di dalamnya, maka kamu jangan lari keluar darinya" 10.

${ }^{24}$ Shafiza Safie, "Pencegahan Penyakit Berjangkit (Covid 19), Kesan dan Hikmabnya Menurut Perspektif Islam" 5, no. 2 (2020):

25 ibnu qoyyim, At-Tibb An-Nabawy, vol. 1 (Muassasah Ar-Risalah Beirut, 1985).

69| Falasifa, Vol. 12 Nomor 2 September 2021 
Dalam hadist tersebut Rasulullah SAW menyinggung tentang wabah, bahkan wabah sudah pernah terjadi pada masa bani Israil dan umat-umat sebelumnya. Jika kita kembali pada sejarah nabi, wabah virus corona yang terjadi saat ini, memiliki kondisi yang hampir sama yaitu penyakit yang menular dan mewabah, sehingga penanganannya pun sama. Penjelasan tersebut mirip dengan kebijakan yang sekarang kita sebut lockdown. Rosululluah SAW melarang seseorang untuk masuk ke daerah yang sedang terjadi wabah, dan melarang penduduk wabah untuk lari dari wabah tersebut. Selain itu juga konsep menjaga jarak, Rasul memerintahkan untuk tidak dekat-dekat atau melihat para penderita kusta yang sifatnya juga menular. Dengan demikian, metode-metode tersebut telah diterapkan sejak zaman Rasulullah untuk mencegah wabah penyakit menular menjalar ke wilayah lain.

Rasulullah juga bersabda:

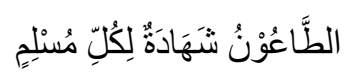

“Tha'un syahadah (berkedudukan syahid) bagi setiap Muslim,” (HR Bukhari, Muslim, dan Ahmad).

Hadist tersebut menjanjikan pahala syahid bagi orang yang bersabar dalam menghadapi wabah dan taat pada Rasullullah SAW dengan tidak keluar dari daerahnya. Orang yang keluar dari wabah akan melewatkan kesempatan unuk meraih pahala syahid dari Allah swt. bagi mereka yang bersabar. Ibnu Hajar Al-Haitami berkata; "Pahala mati syahid hanyalah tercatat bagi mereka yang tidak keluar atau lari dari wabah, dan menetap karena berharap pahala dari Allah swt. ${ }^{26}$ Berharap janji Allah, menyadari jika wabah tersebut menimpanya atau terhindar darinya semua karena takdir dari Allah swt.

c. Pembatasan Shalat berjamaah dimasjid

Kebijakan pelarangan ibadah shalat secara berjamaah merupakan keputusan yang paling kontroversial karena mengundang pro-kontra di tengah masyarakat. Di beberapa tempat terdapat reaksi protes, bahkan ada yang tidak mengindahkan kebijakan ini, meskipun rujukan kebijakan ini adalah Fatwa Majelis Ulama Indonesia. ${ }^{27}$

${ }^{26}$ Alif Jumai Rajab, “Tinjanan Hukum Islam Pada Edaran Pemerintah Dan Mui Dalam Menyikapi Wabah Covid-19” 1, no. 2 (2020): 18.

${ }^{27}$ st. Samsuduha, "Maslahah Kebijakan Pencegahan Wabah Pandemi Covid-19 Dalam Islam" 1 (July 2, 2020). 
Ada yang berdalih dengan hadist Rasulullah yang menjelaskan bahwa seseorang yang meninggalkan sholat Jum'at tiga kali berturut-turut maka ia kafir, meskipun sebenarnya para ulama telah menjelaskan maksud hadist tersebut. bahwa yang dikategorikan kafir adalah mereka yang mengingkari kewajiban jum'at. Dan sangat berbeda dengan kondisi wabah virus COVID-19 saat ini, wabah ini sudah cukup menjadi syarat udzur akan kewajiban sholat jum'at, kemudian bisa diganti dengan sholat Dzuhur di rumah masing-masing. ${ }^{28}$

d. Membaca doa-doa keselamatan

Salah satu contoh doa yang diajarkan oleh Rasulullah SAW adalah "Bismillahilladzi laa yadhurru maasmihi, say'un fil ardhi walafissamaai wahuwa samiul'alim". Apabila mengamalkan dzikir tersebut sebanyak $3 \mathrm{x}$ dipagi dan dipetang hari tidak ada apapun yang dapat membahayakannya. Sesuai pada hadits riwayat Abu Daud, no.5088; Tarmidzi, no.3388; Ibnu Majah, no.3388.

e. Senantiasa meminta perlindungan kepada Allah SWTT.

Kita meminta perlindungan dari wabah virus covid-19 yaitu hanya pada Allah SWT sebelum kita berlindung pada kemampuan diri sendiri atau kemampuan makhluk ciptaan-Nya yang lainnya. Karena Allah SWT penjaga paling baik seperti arti pada Q.S.Yusuf: 64.

f. Berikhtiar dengan melakukan pencegahan.

Ikhtiarnya dengan cara melaksanakan apa yang telah dianjurkan oleh para dokter. Contohnya dengan selalu menjaga kesehatan, dan mencuci tangan secara rutin, tidak keluar rumah kecuali memang keadaan sangat memaksakan untuk keluar rumah, dsb. Hal ini berdasarkan hadits riwayat Bukhari no.3473 dan Muslim no.2218.

g. Bertawakal kepada Allah SW'T

Setelah ikhtiar, maka pada akhirnya semua serahkan kepada Allah SWT. Karena rencana Allah SWT lebih indah. Harus percaya kepada Allah SWT, semuanya sudah diatur. Bahkan saat seseorang tersandung batu sekalipun bisa meninggal apabila Allah SWT sudah berkehendak. Seperti pada Q.S. At- Tholaq:2-3.

h. Yakinlah kesembuhan yang akan diberikan Allah SWT.

Apabila diantara kita sedang terkena wabah virus covid-19 atau terkena penyakit yang lainnya, yakinlah bahwa Allah SWT adalah sebaik-baiknya Penyembuh. Dan yakin kepada Allah SWT bahwa Allah akan menurunkan obat bersama penyakit itu. Seperti sabda Nabi pada Hadits Riwayat Ahmad no: 12186.

${ }^{28}$ Hasse Jubba, "Beradaptasi dengan Bencana: Strategi Beribadah Umat Islam dan Kristen di Tengah Pandemi Covid-19," $2021,14$. 71| Falasifa, Vol. 12 Nomor 2 September 2021 
i. Selalu bersabar dan bersyukur.

Didalam situasi seperti ini perbanyaklah sabar dari pada mengeluh. Pada Hadits Riwayat Muslim no.2999 yang menjelaskan tentang kesabaran dan selalu bersyukur dalam menghadapi kesusahan. Dan pada Q.S Al-Baqarah ayat 155- 157 yang menjelaskan tentang kabar gembira untuk orang-orang yang bersabar.

Selain tidak berlawanan dengan ajaran dan panduan agama Islam, kebijakan-kebijakan pemerintah Indonesia terkait dengan penanganan dan pencegahan penyebaran Covid-19 dikuatkan dengan konsep maqashid syari'ah, pada perwujudan akan perlindungan terhadap manusia, khususnya perlindungan terhadap nyawa manusia (hifdz al-nafs) dan perlindungan terhadap eksistensi ekonomi (hifdz al-maal). ${ }^{29}$

\section{Penutup}

Dalam ajaran agama Islam kita diperintahkan untuk mematuhi Allah, Rasulullah dan pemerintah. Allah SW'T berfirman dalam surat An-Nisa' ayat 59;

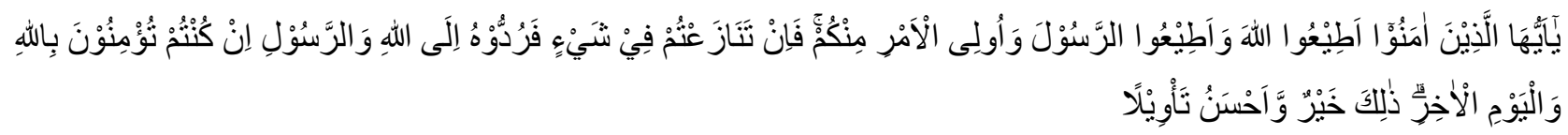

"Wahai orang-orang yang beriman! Taatilah Allah dan taatilah Rasul (Muhammad), dan Ulil Amri (pemegang kekuasaan) di antara kamu. Kemudian, jika kamu berbeda pendapat tentang sesuatu, maka kembalikanlah kepada Allah (Al-Qur'an) dan Rasul (sunnahnya), jika kamu beriman kepada Allah dan hari kemudian. Yang demikian itu lebih utama (bagimu) dan lebih baik akibatnya."

Namun banyak yang mempertanyakan pemerintah yang mana? Yang manapun asal memiliki kebijakan yang tidak menyalahi ajaran agama Islam. Kebijakan-kebijakan yang saat ini diberlakukan seperti pentingnya menjaga kebersihan, melakukan isolasi mandiri di rumah, menjaga jarak (Physical Distancing), Pembatasan Sosial Berskala Besar (PSBB), dan Pembatasan Shalat Berjamaah di Masjid tentunya memiliki maksud mulia atau maslahah yang bermanfaat untuk agama dan jiwa umat serta untuk merealisasikan cita-cita dan tujuan bersama yaitu memutus mata rantai penularan Covid-19.

\section{DAFTAR PUSTAKA}

Almuttaqi „A Ibrahim, "Kekacauan Respons Terbadap COVID-19 Di Indonesia," The Insights, 1, No. 13 (2020).

29 Ahmad Muhtadi Anshor and Muhammad Ngizzul Muttaqin, "Kebijakan Pemerintah Indonesia dalam Pencegahan Penyebaran Corona Virus Disease 2019 (Covid-19) Perspektif Maqashid Syariab,” n.d., 18. 
Titin Nurbidayati

M. Nafiur Rofiq

Ameliyaningsih, Tri * Eri Kartika* and Dimas Teguh Prasetyo. "patuh kepada tuhan atau pemerintab? Culture shock masyarakat muslim indonesia di tengah pandemi covid-19,”2, 3 (November 2020).

Anshor, Ahmad Muhtadi, and Muhammad Ngizzul Muttaqin. "Kebijakan Pemerintah Indonesia dalam Pencegahan Penyebaran Corona Virus Disease 2019 (Covid-19) Perspektif Maqashid Syari’ah,” n.d., 18.

CNN Indonesia. "Membandingkan Wabah SARS, MERS, Dan Virus Corona," March 13, 2020. https://www.cnnindonesia.com/internasional/20200312160647-113482934/membandingkanwabah-sars-mers-dan-virus-corona.

Istiarti, Tinuk and Laksmono Widagdo, "Faktor-Faktor Yang Melatarbelakangi Persepsi Penderita Terhadap Stigma Penyakit Kusta," Promosi Kesehatan Indonesia, 4, no. 1 (2009): 18-24, https://doi.org/10.14710/jpki.4.1.18-24.

Jubba, Hasse. "Beradaptasi dengan Bencana: Strategi Beribadah Umat Islam dan Kristen di Tengah Pandemi Covid19,” 2021, 14.

Kemkes. "Pertanyaan Dan Jawaban Terkait COVID-19," n.d. https:/ / wnw.kemkes.go.id/article/view/20031600011/pertanyaan-dan-jawaban-terkait-covid-19.html.

Louis IX King, Anggita Dwi Ardani, Kasiano Vitalio. "Melawan Corona: Solid Walau Berjarak," 2020, 1-8.

Mongi, Rilauni Angelina, "Gambaran Persepsi Penderita Tentang Penyakit Kusta Dan Dukungan Keluarga Pada Penderita Kusta di Kota Manado," 2012, http://fkm.unsrat.ac.id/wpcontent/uploads/2012/10/Rilauni-Mongi.pdf.

Mona, Nailul. "Konsep Isolasi Dalam Jaringan Sosial Untuk Meminimalisi Efek Contagius (Kasus Penyebaran Virus Corona di Indonesia)." Jurnal Sosial Humaniora Terapan Vol. 2, no.2 (2020): $117-25$.

Mukharom, Mukharom and Havis Aravik, "Kebijakan Nabi Muhammad SAW Menangani Wabah Penyakit Menular Dan Implementasinya Dalam Konteks Menanggulangi Coronavirus Covid19," SALAM: Jurnal Sosial Dan Budaya Syar-I, 7, no. 3 (2020): 239-46, https://doi.org/10.15408/sjsbs.v7i3.15096.

Muharry, Andy, "Faktor Risiko Kejadian Kusta," Kesehatan Masyarakat, 9, no. 2 (2014): 82-174, https://doi.org/10.22146/bkm.25569.

Nugrahani, Andari Wulan. "Update Corona Global 25 Juni 2021 Siang: Jumlah Kasus Infeksi Covid Di Seluruh Dunia 180,7 Juta," n.d. https://www.tribunnews.com/corona/2021/06/25/updatecorona-global-25-juni-2021-siang-jumlah-kasus-infeksi-covid-di-seluruh-dunia-1807-juta. 
N. S. P. Suni, "Kesiapsiagaan Indonesia Menghadapi Potensi Penyebaran Corona," Pusat Penelitian Badan Keahlian DPR RI XII, no. 3 (2020): 13-18.

Rajab, Alif Jumai. “Tinjanan Hukum Islam Pada Edaran Pemerintah Dan Mui Dalam Menyikapi Wabah Covid$19 ” 1$, no. 2 (2020): 18.

Rezki, Annissa dan Nur Rohim Yunus, "Kebijakan Pemberlakuan Lock Down Sebagai Antisipasi Penyebaran Corona Virus Covid-19," Jurnal Sosial Dan Budaya Syar-I, 7, no. 3 (2020): 38-227, https://doi.org/10.15408/sjsbs.v7i3.15083.

Safie, Shafiza. "Pencegahan Penyakit Berjangkit (Covid 19), Kesan dan Hikmahnya Menurut Perspektif Islam" 5, no. 2 (2020): 10.

Samsuduha, St. "Maslahab Kebijakan Pencegahan Wabah Pandemi Covid-19 Dalam Islam” 1 (July 2, 2020).

Sanur, Debora, “Wacana Kebijakan Lockdown Dalam Menghadapi Covid-19 Di Indonesia,"12, no.6 (2020).

Setiawan, Surotul Ilmiyah Adib Rifqi, "Lembar Kegiatan Siswa Untuk Pembelajaran Jarak Jauh Berdasarkan Literasi Saintifik Pada Topik Penyakit Coronavirus 2019 (COVID-19)," 4 (2020):1-9, https://doi.org/.1037//0033-2909.I26.1.78.

Supriatna, Eman. "Wabah Corona Virus Disease Covid 19 Dalam Pandangan Islam," n.d.

Susilo, Adityo, et al., "Coronavirus Disease 2019: Tinjauan Literatur Terkini Coronavirus Disease 2019: Review of Current Literatures," Jurnal Penyakit Dalam Indonesia, 7, no. 1 (2020): 45-67.

Telaumbanua,Dalinama, "Urgensi Pembentukan Aturan Terkait Pencegahan Covid-19 Di Indonesia," QALAMUNA: Jurnal Pendidikan, Sosial, dan Agama, 12, no. 1 (2020): 59-70, https://doi.org/10.37680/qalamuna.v12i01.290.

Tosepu, Ramadhan, Joko Gunawan, Devi Savitri Effendy, La Ode Ali Imran Ahmad, Hariati Lestari, Hartati Bahar, and Pitrah Asfian. "Correlation Between Weather and Covid-19 Pandemic in Jakarta, Indonesia." Science of The Total Environment 725 (2020): 1-4. bttps:/ / doi.org/10.1016/j.scitotenv.2020.138436.

Qoyyim, Ibnu. At-Tibb An-Nabany. Vol. 1. Muassasah Ar-Risalah Beirut, 1985.

Zulva, Tarisa Novita Indana, "Covid-19 Dan Kecenderungan Psikosomatis," Journal of Chemical Information and Modeling, 2020, 1-4, https://doi.org/10.1017/CBO9781107415324.004. 